RESEARCH NOTE

\title{
Alkaloids from Xylopia parvifolia and Xylopia nigricans (Annonaceae)
}

\author{
Shanmugam Puvanendran ${ }^{1}$, Tharmaraja Manoranjan ${ }^{1}$, Anura Wickramasinghe ${ }^{1}$, D. Nedra \\ Karunaratne $^{1}$, Vijaya Kumar', Siril Wijesundara ${ }^{2}$, Gavin Carr ${ }^{3}$, Raymond Andersen ${ }^{3}$ and Veranja \\ Karunaratne $^{1^{*}}$ \\ ${ }^{I}$ Department of Chemistry, Faculty of Science, University of Peradeniya, Peradeniya. \\ 2 Royal Botanic Gardens, Peradeniya. \\ 3 Departments of Chemistry \& Earth and Ocean Sciences, Faculty of Science, University of British Columbia, Vancouver, B.C., Canada.
}

Revised: 13 July 2009; Accepted: 21 August 2009

The family Annonaceae is important phytochemically because of the frequent presence of isoquinoline alkaloids and, more recently on the basis of the restrictive occurrence of a very active class of natural products, the acetogenins ${ }^{1}$. It comprises 130 genera and some 2300 species $^{2}$. Plants of the genus Xylopia have yielded products of different classes such as alkaloids, acetogenins, amides, flavonoids, lignoids, and terpenoids ${ }^{2}$. Members of the family Annonaceae are known to have a variety of alkaloids some of which are reported to have interesting biological properties ${ }^{3}$. Many plants that are known for their toxicity possess useful cytotoxic compounds ${ }^{4}$. Most of the Sri Lankan endemic species of the family Annonaceae have not previously been analysed for their chemical constituents and biological properties.

X. parvifolia (found in Sri Lanka and Southern Deccan peninsula) was collected from Menikthena forest, Central Sri Lanka, in January 2006 and X. nigricans (endemic) from Royal Botanic Gardens, Peradeniya in April 20055. Voucher specimens have been deposited in the Department of Chemistry, University of Peradeniya, Peradeniya.

Air-dried stem bark of $X$. parvifolia $(2 \mathrm{~kg})$ was ground into a powder and sequentially extracted into dichloromethane $\left(\mathrm{CH}_{2} \mathrm{Cl}_{2}\right)$ and methanol $(\mathrm{MeOH})(5 \mathrm{~L}$ each) at room temperature. The $\mathrm{CH}_{2} \mathrm{Cl}_{2}$ extract $(40 \mathrm{~g}$ ) was dissolved in $\mathrm{CHCl}_{3}$ and was partitioned with $2 \mathrm{~N} \mathrm{HCl}$. The aqueous layer was basified with $20 \% \mathrm{NH}_{4} \mathrm{OH}$ and partitioned again with $\mathrm{CHCl}_{3}$. The crude alkaloid mixture
(3 g) obtained on chromatography yielded oxopurpureine (Figure 1a, $24 \mathrm{mg}$ ) as dark orange needles $\left(\mathrm{CH}_{2} \mathrm{Cl}_{2}\right)^{1,6}$, $\mathrm{O}$-methylmoschatoline (Figure $1 \mathrm{~b}, 15 \mathrm{mg}$ ) as orange needles $\left(\mathrm{CH}_{2} \mathrm{Cl}_{2}\right)^{7,8}$ and (+)-laudanidine (Figure 1c, $10 \mathrm{mg}$ ) as brown colour powder'; the crude alkaloid mixture $(4 \mathrm{~g})$ obtained from an acid wash of the $\mathrm{MeOH}$ extract $(50 \mathrm{~g})$ yielded, (-)-discretine (Figure $1 \mathrm{~d}, 60 \mathrm{mg}$ ) as sticky solid $^{10}$, nordicentrine (Figure 1e, $45 \mathrm{mg}$ ) as sticky solid $^{11}$ and dehydrocorytenchine (Figure 1f, $90 \mathrm{mg}$ ) as green crystals ${ }^{12}$.

Air-dried root bark of $X$. nigricans $(5 \mathrm{~kg})$ was ground into a powder and sequentially extracted into $\mathrm{CH}_{2} \mathrm{Cl}_{2}$ and $\mathrm{MeOH}(10 \mathrm{~L}$ each) at room temperature to yield $205 \mathrm{~g}$ of $\mathrm{CH}_{2} \mathrm{Cl}_{2}$ extract and $430 \mathrm{~g}$ of $\mathrm{MeOH}$ extract. The crude alkaloid mixture taken from $\mathrm{CH}_{2} \mathrm{Cl}_{2}$ extract $(1 \mathrm{~g})$ yielded10-methoxyliriodene (Figure $1 \mathrm{~g}, 30 \mathrm{mg}$ ) as yellowish brown amorphous solid ${ }^{8}$. The alkaloid portion of the methanol extract (3.8 g) yielded, (+)-S-reticulin (Figure $1 \mathrm{~h}, 98 \mathrm{mg}$ ) as yellow needles ${ }^{13}$ and oxoxylopine (Figure 1i, $23 \mathrm{mg}$ ) as pale brown powder ${ }^{14}$.

Six alkaloids were isolated from $\mathrm{CH}_{2} \mathrm{Cl}_{2}$ and $\mathrm{MeOH}$ extracts of the stem bark of $X$. parvifolia. Three alkaloids were isolated from the $\mathrm{CH}_{2} \mathrm{Cl}_{2}$ and $\mathrm{MeOH}$ extracts of the root bark of $X$. nigricans. The alkaloids a-f (Figure 1) have previously been isolated from $X$. championii and their antifungal and antioxidant activities reported ${ }^{15}$. (+)-S-reticulin exhibited $67.8 \%$ antioxidant activity compared to the standard DL- $\square$ Tocopherol(55.8\%) in the 2,2-Diphenyl-1-picrylhydrazyl (DPPH) radical scavenging assay ${ }^{16}$. 
<smiles>COc1cc2c(cc1OC)-c1c(OC)c(OC)c(OC)c3ccnc(c13)C2=O</smiles>

a

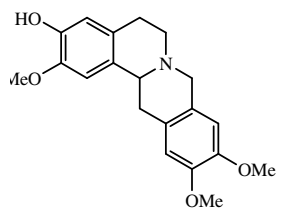

d

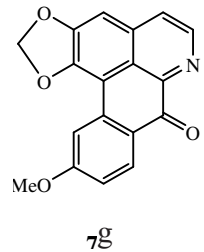

78

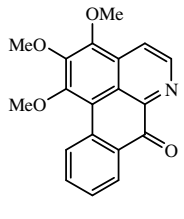

b
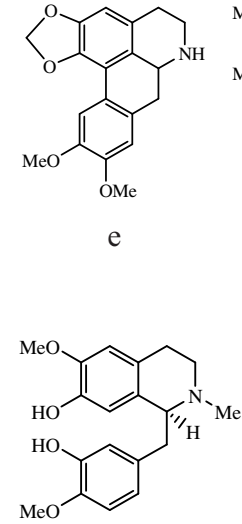

$\mathrm{h}$

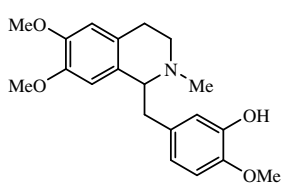

c

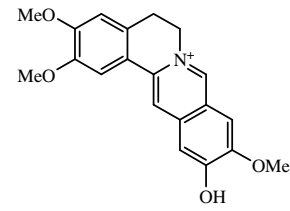

f

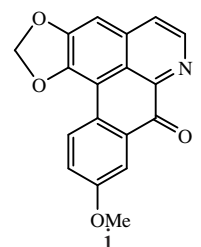

Figure 1: Alkaloids isolated from stem bark of $X$. parvifolia (a-f) and root bark of $X$. nigricans (g-i)

Spectral data $\left[{ }^{1} \mathrm{H},{ }^{13} \mathrm{C}\right.$ nuclear magnetic resonance (NMR) and mass] and physical data (m.p., Co-TLC, optical rotation) of reported or isolated compounds were used in the identification of the alkaloids a-i ${ }^{1,6-13}$

\section{Acknowledgment}

Authors thank the National Science Foundation and the National Research Council, Sri Lanka for financial assistance.

\section{References}

1. Chang F.R., Wei J.L., Teng C.M. \& Wu Y.C. (1998). Antiplatelet aggregation constituents from Annona purpurea. Journal of Natural Products 61(12): 14571461.

2. Moreira I.C., Lago J.H.G. \& Roque N.F. (2005). Sesquiterpenes, diterpenes, steroids and alkaloids from branches of Xylopia brasiliensis Spreng (Annonaceae). Biochemical Systemetics and Ecology 33(9): 948-951.
3. Wijeratne E.M.K., Hatanaka Y., Kikuchi T., Tezuka Y. \& Gunatilaka A.A.L. (1996). A dioxoaporphine and other alkaloids of two Annonaceous plants of Sri Lanka. Phytochemistry 42(6): 1703-1706.

4. Kingston D. (1992). Taxol and other anticancer agents from plants. In: New Drugs from Natural Source. pp. 101119. Information Press, Oxford.

5. Huber H. (1985). Annonaceae. In: A Revised Handbook to the Flora of Ceylon. vol V. (Eds. M.D. Dassanayake \& F.R. Fosberg). pp. 56-61. Amerind Publishing Pvt. Ltd., New Delhi.

6. Sonnet P.E. \& Jacobson M. (1971). Tumour inhibitors II: cytotoxic alkaloids from Annona purpurea. Journal of Pharmceutical Sciences 60(8): 1254-1256.

7. Marsaioli A.J., Aderbat F.M., Edmundo A.R. \& Francisco D.A.M.R. (1980). ${ }^{13} \mathrm{C}$ NMR analysis of some oxoaporphine alkaloids. Phytochemistry 19(5): 995-997.

8. Harrigan G.G., Gunatilaka A.A.L., Kingston D.G.I., Chan G.W. \& Johnson R.K. (1994). Isolation of bioactive and other oxoaporphine alkaloids from two Annonaceous plants Xylopia aethiopica and Miliusa cf. Banacea. Journal of Natural Products 57(1): 68-73.

9. Blanchfield J.T., Sands D.P.A., Kennard C.H.L., Byriel K.A. \& Kitching W. (2003). Characterisation of alkaloids from some Australian Stephania (Menispermaceae) species. Phytochemistry 63(6): 711-720.

10. Hocquemillar R., Debitus C., Roblot F., Cavé A. \& Jacquemin H. (1984). Alkalo $\square$ des des Annonacées, XLVIII. alkalo $\square$ des des écorces de Guatteria discolour. Journal of Natural Products 47(2): 353-362.

11. Likhitwitayawuid K., Angerhofer C.K., Chai H., Pezzuto J.M., Cordell G.A. \& Ruangrungsi N. (1993). Cytotoxic and antimalarial alkaloids from the tubers of Stephania pierrei. Journal of Natural Products 56(9): 1468-1478.

12. Jossang A., Leboeuf M., Cavé A. \& Pusset J. (1991). Alkalo $\square$ des des Annonacées. 96. déhydroxylopine et déhydrocorytenchine, nouveaux alkalo $\square$ des isoquinoléiques isolés de Xylopia viellardi. Journal of Natural Products 54(2): 466-472.

13. Hsieh T.J., Chang F.R. \& Wu Y.C. (1999). The constituents of Cananga odorata. Journal of the Chinese Chemical Society 46(4): 607-611.

14. Chen C.Y., Chang F.R. \& Wu Y.C. (1997). The constituents from the stems of Annona cherimola. Journal of the Chinese Chemical Society 44(3): 313-319.

15. Puvanendran S., Wickramasinghe A., Karunaratne D.N., Carr G., Wijesundara D.S.A., Andersen R. \& Karunaratne V. (2008). Antioxidant constituents from Xylopia championii. Pharmaceutical Biology 46(5): 352-355.

16. Yen G.C. \& Duh P.D. (1994). Scavenging effect of methanolic extracts of peanut hulls on free radical and active oxygen species. Journal of Agricultural and Food Chemistry 42(3): 629-632. 